\title{
Reinventing the concept of homo novus in Rome: Cicero as Horace's role model
}

\author{
Camilla Ferreira Paulino da Silva ${ }^{1^{*}}$ \\ ${ }^{1}$ Secretaria de Educação do Espírito Santo, Aracruz/ES - Brasil \\ Leni Ribeiro Leite ${ }^{2 * *}$ \\ ${ }^{2}$ Universidade Federal do Espírito Santo, Vitória/ES - Brasil
}

\begin{abstract}
This paper identifies similarities between Horace's and Cicero's use of the term Homo novus as a positive connotation, which contrasts with the then prevailing view of the outsider as a negative element. We suggest that Horace might have drawn on elements from Cicero's works to support the defense of his position within Roman society.
\end{abstract}

Keywords: Roman social orders: equestrians; novi homines; Auctoritas; Horace; Cicero.

\section{Reinventando o conceito de homo novus em Roma: Cícero como modelo para Horácio}

\section{RESUMO}

Este artigo tem por objetivo observar as semelhanças entre o uso do termo homo novus pelos autores romanos Cícero e Horácio, com uma conotação positiva, em contraste com a visão do outsider como um elemento negativo. O que pretendemos sugerir é que Horácio pode ter se utilizado de elementos das obras de Cícero como forma de sustentar uma defesa de sua própria condição na sociedade romana.

Palavras-chave: sociedade romana: equestres; novi homines; Auctoritas; Horácio; Cícero.

DOI: http://dx.doi.org/10.1590/2237-101X02104503

Artigo recebido em 30 de julho de 2019 e aceito para publicação em 9 de dezembro de 2019.

* Professora da Secretaria de Educação do Espírito Santo, Aracruz/ES - Brasil. E-mail: camillapaulino@ gmail.com. ORCID: https://orcid.org/0000-0001-9715-8258.

** Professora da Universidade Federal do Espírito Santo / Centro de Ciências Humanas e Naturais, Vitória/ ES - Brasil. Bolsista CNPq PQ-2. E-mail: leni.ribeiro@gmail.com. ORCID: http://orcid.org/0000-00016600-7692.

We would like to thank Dr. Stephen Harrison (CCC, Oxford) for the valuable commentaries and contributions to this article. 


\section{Reinventando el concepto de homo novus en Roma: Cícero como modelo para Horacio}

\section{RESUMEN}

Este artículo tiene por objetivo observar las semejanzas entre el uso del término homo novus por los autores romanos Cícero y Horacio, con una connotación positiva, en contraste con la visión del outsider como un elemento negativo. Lo que pretendemos sugerir es que Horacio puede haber utilizado elementos de las obras de Cícero como forma de mantener una defensa de su propia condición en la sociedad romana.

Palabras clave: sociedad romana; jinetes; novi homines; Auctoritas; Horacio; Cícero.

Cicero and Horace were contemporaries for some years, though, perhaps surprisingly, there is no indication in ancient sources of a possible relationship between them. When Horace was only two years old, Cicero was already an illustrious orator ready to take on the consulship of $63 \mathrm{BCE}$. When Cicero was murdered in $43 \mathrm{BCE}$, the twenty-two year old Horace was getting ready to fight against the political group responsible for the senator's death. It was unlikely that the young Horace ignored Cicero, and it is likely that the poet had met the orator's son in Athens, during their philosophical studies. ${ }^{3}$ Cicero's son and Horace both fought for the same cause in Philippi (42 BCE), and both shared the experience of that defeat. Nevertheless, as Alberte demonstrated, even though comparisons have already been drawn among scholars between Cicero and Horace, they seem to have concentrated mainly on their rhetorical and literary style (ALBERTE, 1989). In this paper, we argue that there are more than coincidental parallels between Cicero and Horace, mainly regarding their status as novi homines, and we would like to suggest that Horace might have drawn more than just inspiration from the elder politician in regards to establishing his position within Roman society.

\section{Defining a homo novus}

As Van der Blom (2010, p. 35) has already demonstrated, the ancients have no precise definition for the terms novus homus or nobilis, ${ }^{4}$ which made that scholar rightly draw

\footnotetext{
${ }^{3}$ Cic. Ad Fam. 16.21. [CICERO. Letters to Friends. Edited and translated by D. R. Shackleton Bailey. Cambridge, MA: Harvard University, 2001].

${ }^{4}$ Nevertheless, many scholars tried to define the terms, as, for instance, did Mommsen (1887), Gelzer (1912),
} 
attention to the rhetorical dispute around them. These are terms with no legal accuracy, but that were constantly used to refer to some individual or group, its meaning permanently changing according to the speaker's aims and context (VAN DER BLOM, 2010, p. 37). Tentatively, we can, as Dugan did, define homo novus as a political outsider, someone with no family with a prestigious past; that is, a free man with no relatives that had fulfilled high offices (DUGAN, 2005, p. 1). According to this definition, both Cicero and Horace would be accurately described as homines novi. Both authors also use the terms in their own works, but in both cases, the novus homo is seen as a positive figure: his condition is something to be praised and highlighted.

Clearly, this eagerness to present novitas as praiseworthy, however, points at the existence of a counter-discourse against which both men had to fight (VAN DER BLOM, 2010, p. 42). Ancestry seemed to be an important issue in the process of construction of auctoritas in Rome, and just as with Cicero throughout his career. Horace had to face this inadequacy, since he had no glorious family past to lay upon. The weight of ancestral tradition can be exemplified by the ius imaginum, i.e., a noble Roman's right to carry and exhibit the effigies of his forefathers in his atrium. Only patrician families had this right, at first; as time went by, however, the descendants of a Roman that had reached some curule magistracy could also exhibit the images of their ancestors in the domus and funeral processions. This right was of substantial relevance, for it could also be revoked in cases of damnatio memoriae, for example (STROUP, 2010, p. 254). Van der Blom states that Cicero's position was ambiguous in Roman society, since, at the same time that the orator showed pride in his conquests and deeds, considering himself on the same level of auctoritas as the other members of the Roman nobilitas, these noblemen never let Cicero forget that he was a homo novus, the first one of his family to reach the Senate and, therefore, someone who could not boast of a glorious past (VAN DER BLOM, 2010, p. 24-25).

Cicero and Horace were men who ascended socially due to their education - it was because of their individual instruction that Cicero became a politician and Horace, a poet -, and, each in their own manner, had to deal with the fact that in some measure they were outsiders. Sallust (Cat. 23) , for example, reminds us that most of the members of the nobilitas considered it outrageous that a new man like Cicero could reach the consulate, which would violate that magistracy. Catiline, after hearing Cicero speak against him in the Senate, mentioned how absurd it was that a person like this man of obscure roots would position himself as the savior of the res publica, offending someone whose patrician family had provided so many services to the Romans, Cicero being nothing more than an

Brunt (1982), Bailey (1986) e Burckhardt (1990). For a panorama of this discussion, see Van Der Blom (2010, p. 35-60).

${ }^{5}$ SALLUST. The War with Catiline. The War with Jugurtha. Edited by John T. Ramsey. Translated by J. C. Rolfe. Cambridge, MA: Harvard University, 2013. 
"a tenant of the city of Rome"6 (Sal., Cat. 31). Cicero (Phil. 6.17) ${ }^{7}$ also marks this position when showing gratitude towards the Romans for bestowing upon him so many important duties, although he was "a se ortum," "born from himself," in other words, a man with no noteworthy ancestry. ${ }^{8}$ The same Cicero (Leg. Agr. 2.3), ${ }^{9}$ in a speech made during his consulship, mentions the fact that he was the first homo novus to reach that position in a considerable amount of time, a claim that adds value to his feats, but also signals that, even in the midst of the social transformations that took place during the first century CE, the traditional nobilitas in Rome still ensured their status quo, making it rare and difficult for an outsider to reach the highest position in the res publica.

As in Elias' investigation about the community of Winston Parva (ELIAS, 2000), we believe that, within first century BCE Rome, there was a group of established citizens and a group of outsiders, who are permanently negotiating their relationship. The established would be the ones whose families led the res publica for many generations, such as Catiline; and the outsiders were the novi homines, ${ }^{10}$ who came from the provinces and sought to rise socially through the cursus honorum or, such as Horace, through Literature. As Atkins argues, the members of the old aristocracy justify their own situation through the mos maiorum, not only because education was based upon it (ATKINS, 2000, p. 481-482), but also because it was a way of marking out their privileged position, since their imminence was not assured by law, but by the Roman habit of bowing to the ancestors; "the family, rather than the individual, was the fundamental place of reputation and pride" (p. 482). Men like Cicero and Horace did not have this legacy to uphold them, which meant they had to find other ways to secure and defend their own social positions, something they did, as we shall argue, mainly through discursive strategies. ${ }^{11}$

\section{Reinventing the concept of homo novus}

Differently from the outsiders of Elias' analysis, who accepted the condition of being stigmatized for not belonging to the older families of Winston Parva, what we see both

\footnotetext{
6 "inquilinus civis Urbis Romae".

${ }^{7}$ CICERO. The Orations of Marcus Tullius Cicero, v. 4. Translated by C.D. Yonge. London: H.G. Bohn, 1856.

${ }^{8}$ CICERO, in Verr. 2.2.174, also seems to differentiate himself from other nobles: "[...] ab homine non nostri generis, non ex equestri loco profecto", "[...] not by a man of our body, not by a man born of the equestrian order". CICERO. The Orations of Marcus Tullius Cicero, v. 1. Translated by C.D. Yonge. London: H. G. Bohn, 1856. ${ }^{9}$ CICERO. The Orations of Marcus Tullius Cicero, v. 2. Translated by C.D. Yonge. London: H. G. Bohn, 1856. ${ }^{10}$ About the strategies of the novi homines to supplant the prejudice from the old nobilitas, see Wiseman (1971) and Syme (1986).

${ }^{11}$ Besides one's ancestrality, the way through which someone made a fortune was also of great importance to their social status: Horace's father, for example, was not poor, but had to do business to make his fortune, which, to the nobilitas, marked him as an inferior (Cf. WISEMAN, 1971, p. 72-74).
} 
in Cicero and Horace is that they sought to be a part of the elite, building ways to justify their auctoritates (ELIAS, 2000, p. 20). Cicero, for example, by reaching out to respectable Republican figures such as Cato as characters in his dialogues and examples in his speeches was constructing his own ancestry, connecting himself to the community's mos maiorum, by showing respect to people whose practices had been fundamental to leading the res publica (DOLGANOV, 2008, p. 30). In the In Verrem orations (2.5.180), ${ }_{12}^{12}$ Cicero points out he does not have the same benefits as the nobles to whom, even when they sleep, Roman honors are assured; right after, though, he evokes a recommendation from Cato to defend himself, calling him "man of great knowledge and care"13, to whom it was best being recommended to the Roman people due to one's own virtues rather than being born from illustrious parents ${ }^{14}$. Soon after, Cicero calls to mind Quintus Pompey, who, although "a man of low and obscure upbringing"15, reached the highest honors, through his own effort. He also quotes Gaius Fimbria, Gaius Marius and Gaius Coelius, remembering that, although they had found strong opposition, they also managed glorious careers. Finally, Cicero brings attention to the fact that the homines novi had to be always vigilant, because their diligence and virtue made other members of the nobilitas envious, trying to damage them whenever they could. For the orator, it is rare for members of the older families to be kind to the new men, who were always seen as "different in birth and nature, therefore different from us through character and desire"16 (Cic., Verr. 2.5.181-2). In the fragment Ad A. Hirtium (3) ${ }_{17}^{17}$ Cicero develops what Wiseman calls an "advanced form of the new man's ideology," (WISEMAN, 1971, p. 11) by affirming that nobility is nothing but recognized virtue, and therefore a person that had been, throughout the years, gathering glory, should not care about the lack of nobility of their ancestry. ${ }^{18}$

In a letter written in 50 BCE, Cicero (Fam. 3. 7. 5) ${ }^{19}$ defends himself from an alleged comment made by Appius, who would have refused to meet with Cicero due to the latter being a parvenu and not a Lentulus. The speaker questions how Appius, an experienced

\footnotetext{
${ }^{12}$ CICERO. The Orations of Marcus Tullius Cicero, v. 1. Translated by C.D. Yonge. London: H. G. Bohn, 1856. 13 "hominis sapientissimi et vigilantissimi".

${ }^{14}$ Venit mihi in mentem M. Catonis, hominis sapientissimi et vigilantissimi; qui cum se virtute non genere populo Romano commendari putaret, cum ipse sui generis initium ac nominis ab se gigni et propagari vellet [...], "For the case of Marcus Cato, a most wise and active man, occurs to me; who, as he thought that it was better to be recommended to the Roman people by virtue than by high birth, and as he wished that the foundation of his race and name should be laid and extended by himself [...]. Cic. In Verr. 2.5.180.

15 " humili atque obscure loco natus".

16 "quasi natura et genere diiuncti sint, ita dissident a nobis animo ac voluntate".

${ }_{17}$ CICERO. Letters to Quintus and Brutus. Letter Fragments. Letter to Octavian. Invectives. Handbook of Electioneering. Edited and translated by D. R. Shackleton Bailey. Cambridge, MA: Harvard University, 2002.

18 "cum enim nobilitas nibil aliud sit quam cognita virtus, quis in eo quem veterascentem? videat ad gloriam generis antiquitatem desideret?"

${ }^{19}$ CICERO. Letters to Friends. Edited and translated by D. R. Shackleton Bailey. Cambridge, MA: Harvard University, 2001.
} 
intellectual, could think that family distinctions were worth more than a man's virtue; Cicero also says that even before he reached a prominent place in the Roman society he had not allowed himself to admire aristocratic surnames, but the men that gave those surnames to the future generations, that is, the men that made those surnames famous due to their deeds. Towards the end of the excerpt, he indicates that Appius should read Athenodorus Cananites to learn what real nobility ( $\varepsilon \dot{\gamma} \gamma \varepsilon \dot{v} \varepsilon\llcorner\alpha)$ was. In this sense, Cicero defends the idea that a homo novus could claim a connection with noble ancestors and his descendants through virtue, more important than blood ties. This was a concept which Cicero brought forth during his whole career, which allows us to detect that probably many depreciated the novi homines. ${ }^{20}$

Horace, who had to face the same problem Cicero had fought against a few years earlier, had the latter's body of work to follow, in search of ways of dealing with the problem of his lack of noble ancestry. Horace found himself in a more peculiar position, since he could not, as a novus homo, totally praise the importance of an old family name, but, as friend to Maecenas and Augustus, could also not show complete contempt for such standards. In the opening lines of Satire 1.6 (v. 1-6), ${ }^{21}$ he praises Maecenas and his ancestry, but highlights the fact that, although descending from honorable ancestors, his patron did not despise people of minor ancestry such as Horace:

\footnotetext{
${ }^{20}$ Such was, for example, Hortensius (Cic. Verr. 3.7), who scorned the new men, doubting their virtues and abilities. Also in Pro Murena (Mur. 16) Cicero shows his approval of the ones who, without noble ancestry, manage to stand out due to their abilities: "Tua vero nobilitas, Ser. Sulpici, tametsi summa est, tamen hominibus litteratis et historicis est notior, populo vero et suffragatoribus obscurior. Pater enim fuit equestri loco, avus nulla inlustri laude celebratus. Itaque non ex sermone hominum recenti sed ex annalium vetustate eruenda memoria est nobilitatis tuae. Qua re ego te semper in nostrum numerum adgregare soleo, quod virtute industriaque perfecisti ut, cum equitis Romani esses filius, summa tamen amplitudine dignus putarere. Nec mihi umquam minus in $Q$. Pompeio, novo homine et fortissimo viro, virtutis esse visum est quam in homine nobilissimo, M. Aemilio. Etenim eiusdem animi atque ingeni est posteris suis, quod Pompeius fecit, amplitudinem nominis quam non acceperit tradere et, ut Scaurus, memoriam prope intermortuam generis sua virtute renovare.", "But your nobility, O Servius Sulpicius, although it is most eminent yet it is known rather to men versed in literature and history, but not much so to the people and to the voters. For your father was in the rank of the knights, your grandfather was renowned for no conspicuous action. So that the recollection of your nobility is to be extracted not from the modern conversation of men, but from the antiquity of annals. So that I also am accustomed to class you in our number, because you by your own virtue and industry, though you are the son of a Roman knight, have yet earned the being considered worthy of the very highest advancement. Nor did it ever seem to me that there was less virtue in Quintus Pompeius, a new man and a most brave man, than in that most high-born man, Marcus Aemilius. Indeed, it is a proof of the same spirit and genius, to hand down to his posterity, as Pompeius did, an honourable name, which he had not received from his ancestors; and, as Scaurus did, to renew the recollection of his family which was almost extinct" (CICERO. The Orations of Marcus Tullius Cicero, v. 2. Translated by C. D. Yonge. London: H. G. Bohn, 1856.) As in this passage, Cicero usually takes ingenium, industria and virtus as qualities to be praised in men who, not belonging to the old nobilitas, still reached notoriety.

${ }^{21}$ HORACE. Satires and Epistles. Translated by John Davie. Oxford: Oxford University, 2011.
} 
Although, Maecenas, of all Lydians who inhabit Etruria's lands no one is of nobler birth than you, although your ancestors on your mother's and father's side alike held power over mighty legions in days gone by, you do not follow most men's habit and turn your nose up at those of unknown birth, such as myself, a freedman's son. ${ }^{22}$

In this excerpt, the parallel between the traditional Roman, Maecenas, and the outsider, Horace, is evident, the former from an illustrious lineage, the latter from unknown ancestors. The description of Maecenas' ancestors commanding legions corresponds perfectly to the value given to military action in nobilitas (DUQUESNAY, 2009, p. 80). The poet, on the other hand, without a glorious family history, is despised by others, just like Cicero was. Following Elias (2000, p. 22), we could see the poet pointing out to his own stigmatization, used by the elite (in this case, part of the Roman nobilitas) to preserve their own identities and sovereignty, keeping away people like Horace. It must be emphasized that the stigmatization existed even in the highest orders. Wiseman, arguing about the indistinction in economic terms between senators and equestrians, demonstrates that the first order had no qualms in pointing out the difference between the orders, using tools such as the use of a special golden ring, different seats in the theaters, and the latus clavus (WISEMAN, 1971, p. 66-68). The author shows as well that within the highest ranks there was also a differentiation between older and newer members, so that equestrians whose families belonged to the order for a long time, that is, who were heirs and not newcomers, tended to protect themselves against the new members, "creating stratified systems of status inside the moneyed class which they at least regarded as no less significant than the distinction between the moneyed class itself and the rest of the populace" (p. 69).

Horace seems to refuse this system. ${ }^{23}$ To Horace, as to Cicero, virtus is brought up as a more important value when compared to lack of ancestry, something observed, for example, in Epistle 1.20 (v. 20-22), in which the poet registers his obscure birth, although accentuating that though he lacks in genus he overflows in virtus. The way to value his image and justify his presence among noble people such as Maecenas is through the appeal to his excellent moral conduct, thanks to the education provided by his father - two elements that, as we have seen, are also used by Cicero as equivalent to noble birth. The praising of Maecenas's

\footnotetext{
${ }^{22}$ Non quia, Maecenas, Lydorum quidquid Etruscos/ incoluit finis, nemo generosior est te, / nec quod avus tibi maternus fuit atque paternus/ olim qui magnis legionibus imperitarent, / ut plerique solent, naso suspendis adunco/ ignotos, ut me libertino patre natum.

${ }^{23}$ In Satire 2.3 (v. 307 e ss) the character Damasipus scorns the poet, calling him insane for wanting to compare and excessively imitate people of high lineage like Maecenas. And the character's accusations is coherent, since in the scenography of the satires the poet is full of vices, therefore Horace could never resemble the noble patron. But it is curious to think about the likelihood of said assertion, because it is possible that Damasipus' judgement in many levels expresses what some people could think about Horace, an audacious homo novus. That is in contrast with what appears later, in Epistle 1.19, where Horace is imitated by others, now that he himself is a powerful and successful man (OLIENSIS, 1998, p. 174).
} 
preferring people by their character and not their birth (Sat. 1.6, v. 7-8; 1.9, v. 54-5) is self praise and a way of proposing that there other values should be recognized by the Romans. ${ }^{24}$ Horace has, nonetheless, a benefit that Cicero lacked: the open approval of a very wellregarded living person. As Oliensis affirms, when dictating that no one is more noble than Maecenas, who does not despise people due to their ancestry, carefully choosing his friends (v. 50-2), Horace is using the patron as a shield against other people's accusations - whoever accused the poet of being unworthy would, by association, be accusing Maecenas, who was a rich and powerful personal friend of Octavius, of not knowing how to choose the people with whom he was related (OLIENSIS, 1998, p. 32). The verses where the poet criticizes people who praise only old nobility are very emphatic, "that in its stupid way often bestows honors / on the unworthy and is foolishly enslaved to renown, that gapes in / admiration at titles of honor and ancestral busts" (Hor. Sat. 1.6, v. 15-7). ${ }^{25}$ This is very strong criticism: the tituli to which Horace refers to in this excerpt were votive or funerary inscriptions engraved in different materials that marked the praise of an individual (DAREMBERG; SAGLIO, 1877, p. 347); the imagines of the ancestors are marks of social distinction, preserved by the noble Romans in the atria of their houses to show the greatness of their families, associated with the sacred scope and to the rites of perpetuation of the memory of a gens (FLOWER, 1999; MARTINS, 2014, p. 15-16; STEWART, 2011, p. 10). In the funeral processions, for example, it was traditional for the family of the deceased to take his and other ancestors' imagines, emphasizing publicly the prestige of the gens. In the sphragis of Epistle 1.20 (v. 1928) the poet plays with that tradition, and writes his own votive epitaph like a nobleman's: Horace pretends at self-immortalization by joking about himself, ${ }^{26}$ inverting what would be common in traditional inscriptions, emphasizing that what he lacks by birth, he obtained by virtue ("so adding to my virtues whatever / you subtract from my birth;" ${ }^{27}$, v. 22).

\section{Dealing with the nobilitas}

Horace chooses to criticize the symbols with which the nobilitas expressed their auctoritas to the Roman society, and which the poet could not claim. ${ }^{28}$ According to the poet, backed

\footnotetext{
${ }^{24}$ Ian DuQuesnay (2009, p. 84) says the visions linked to Maecenas in this satire demonstrates that he approved the presence of novi homines in high positions if the individual had virtus and was born free.

25 "stultus honores/ saepe dat indignis et famae servit ineptus, / qui stupet in titulis et imaginibus". Horace (Sat. 1.6, v. 12 e ss) lists, for example, Valerius Laevinius, descendant from a noble family, to emphasize that his ancestry did not stop him from being worth less than an as.

26 "corporis exigui, praecanum, solibus aptum, / irasci celerem, tamen ut placabilis essem", "a fellow of small stature, grey / before my time, fond of the sun's rays, quick to anger but not hard to / win round again" (Ep. 1.20, v. 24-5). HORACE. Satires and Epistles. Translated by John Davie. Oxford: Oxford University, 2011. 27 "ut quantum generi demas, virtutibus addas;".

${ }^{28}$ Ian DuQuesnay (2009, p. 85) interprets that, in this criticism to the ones who were frantic against the im-
} 
up by the sound judgment of Maecenas (Sat. 1,6, v. 12-22), having famous ancestry was not enough for someone to be considered worthy and, therefore, not having it was not a demerit to his social situation. Therefore, in Satire 1.6 (v. 89-92), after narrating the sophisticated education his father gave him, the poet stresses: "In no way, as long as I'm in my right mind, could I be ashamed / of such a father, and so I wouldn't defend myself as a great number / do, saying that it's not through any fault of their own that they don't / have freeborn or famous parents". ${ }^{29}$

This strategy of weakening the appeal to ancestry from the traditional elite seems to follow the same rules applied by Cicero, as shown above. In Brutus (62), ${ }^{30}$ Cicero mentions the practice, common among the members of noble families, of writing the eulogy pronounced in the funeral procession. However, Cicero makes the following remark:

Yet by these laudatory speeches our history has become quite distorted; for much is set down in them which never occurred, false triumphs, too large a number of consulships, false relationships and transitions of patricians to plebeian status, in that men of humbler birth professed that their blood blended with a noble family of the same name, though in fact quite alien to them; as if I, for example, should say that I was descended from Manius Tullius the patrician, who was consul with Servius Sulpicius ten years after the expulsion of the kings. ${ }^{31}$

Cicero downplays the importance of those records, a cause of pride among the members of the nobilitas, mocking the fact that even he could, if he so desired, trace a noble ancestral lineage that dated to former eras. But he did not need that, just like Horace claims not to be vexed for having no noble lineage.

It is important to stress, of course, that this does not mean that Cicero and Horace fought against the then current order, since the dialogue with the nobilitas, through the bonds of amicitia, is precisely a way of reinforcing their auctoritates. ${ }^{32}$ The decreasing of the

ages of Horace's ancestry, he was vituperating the ones, in the context of the conflict between Octavius and Sextus Pompey, who let themselves be taken by the images of the last one's father, namely, Pompey the Great. 29 "nil me paeniteat sanum patris huius, eoquel non, ut magna dolo factum negat esse suo pars, / quod non ingenuos habeat clarosque parentes, / sic me defendam.[...]".

${ }^{30}$ CICERO. Brutus. Orator. Translated by Hendrickson; Hubbell. Cambridge, MA: Harvard University, 1971. 31 "quamquam his laudationibus historia rerum nostrarum est facta mendosior. multa enim scripta sunt in eis quae facta non sunt: falsi triumphi, plures consulatus, genera etiam falsa et ad plebem transitiones, cum homines humiliores in alienum eiusdem nominis infunderentur genus; ut si ego me a $M^{\prime}$. Tullio esse dicerem, qui patricius cum Ser. Sulpicio consul anno x post exactos reges fuit". CICERO. Brutus. Orator. Translated by Hendrickson; Hubbell. Cambridge, MA: Harvard University, 1971.

${ }^{32}$ Cicero (Off. 2.46), for example, commends the importance of a young man to procure and keep friendships with noble people (CICERO. On Duties. Translated by Walter Miller. Cambridge, MA: Harvard University, 1913). The value of friendship permeates the whole Epistles of Horace, such as when the poet advises Florus to reconcile with Munatius, in Epistle 1.3. Ellen Oliensis (1998, p. 31), analyzing the verses 20-2 of Satire 1.6, shows that Horace defends the status quo by supporting that someone who was not born from a free father should be withdrawn from the Senate. 
weight of ancestry is, however, an important rhetorical strategy to emphasize that although they did not belong to a great family they still had value. To Horace, said value would come from the fact that he shared with renowned people, such as Maecenas and Augustus, the same cultural knowledge acquired not by family heritage but by the efforts made in a formal education that raised his social class. The same occurred to Cicero, who, as we have seen, presented himself as linked to notable men such as Cato, who, although not part of his family, was evoked as if he were his ancestor, since he had also been a homo novus who had reached a privileged position in Rome (Cic. De Rep, 1.1; Verr. 180) ${ }^{33}$. Cicero praises Cato stressing not only his political practice, but also the fact that he was the first to leave writings worth remembering, marking a link between the speaker and the Roman ancestor, both of them politicians and writers. ${ }^{34}$ In his Pro Archia poeta oratio, Cicero summarizes in one remarkable sentence how the example of illustrious men should serve as a guide not only to their blood descendants, but to everyone, as a way to defend himself from this personal gap: "Lastly, all those great men, the Maximi, the Marcelli, and the Fulvii, are done honor to, not without all of us having also a share in the panegyric" 35 (Cic., Arch. 22). ${ }^{36}$

\section{Educational success as a key for auctoritas}

The rhetorical, philosophical and poetical formation of the Roman man was his cultural capital, that is, his assets that, in the economy of the symbolic trades, promoted his social distinction. This type of knowledge, acquired and reinforced in his day everyday practices, could define the position of an individual in that society, because they conveyed power (BOURDIEU, 1985, p. 242-244). Horace, for instance, in the Epistle 1.3, when speaking to Julius Florus about some men who gathered around the future emperor Tiberius, asked for news about the poetic works that they were supposedly writing. Writing was a social practice, and literature was cultural capital registered in the scope of the elite: by demonstrating that distinguished people also practiced and were interested in literature, Horace is simultaneously comparing himself to them and incorporating value to his work and position.

The value attributed to a work was, in Rome, inherent to the social condition of the author; thus the production of an individual that belonged to higher orders had more credit than that of someone who came from a lower category (DOLGANOV, 2008, p. 27).

${ }^{33}$ CICERO. On the Republic. On the Laws. Translated by Clinton W. Keyes. Cambridge, MA: Harvard University, 1928.

${ }^{34}$ Cicero also insists on mentioning the coincidental fact, in this same line, that Cato had been quaestor exactly 140 years before Cicero's consulship, emphasizing that this would never be remembered if not for Ennius' record (Brut. 60)

35 "Omnes denique illi Maximi, Marcelli, Fulvii, non sine communi omnium nostrum laude decorantur".

${ }^{36}$ CICERO. The Orations of Marcus Tullius Cicero, v. 2. Translated by C. D. Yonge. London: H. G. Bohn, 1856. 
Therefore, controlling the way in which this social condition appears in the work, as Horace does, was essential to the legitimacy of his speech, while building the idea that ancestry was not the only support for a person to be considered worthy in Rome. He is directly valuing his belonging to that society and negotiating that point of view. Van der Blom argues that one of the strategies used by Cicero to work around his lack of ancestry and creating his own arsenal of exempla that would confer him auctoritas was emphasizing his educational trajectory, placing his effort and dedication of keys to a well succeeded career: everything that he will assign as essential to an excellent speaker, in his works, matches all the subjects he had studied before initiating his cursus honorum in Rome, with the quaestorship, in 75 BCE (VAN DER BLOM, 2010, p. 33-34). In Brutus (151), for example, he narrates his trajectory to acquire the ability in the art of speech, adding that he went to Rhodes to perfect his technique. The orator shows he took civil and criminal cases before entering the Forum, as training, at the same time as he studied with Molus, famous teacher and lawyer (Cic. Brut. 311-3). Presenting his effort and dedication, Cicero puts himself as an example to the ones who, just like him, did not have powerful ancestors who could serve as a springboard. ${ }^{37}$

In the exordium to the Pro Archia oration, Cicero refers to his own talent as a speaker arguing that in great measure his success was influenced by the poet Archias, who had encouraged him to study from early on - if someone, perhaps, found it strange that a lawyer conferred credit to a poet, Cicero argues that it should not be like that, "In truth, all the arts which concern the civilizing and humanizing of men, have some link which binds them together, and are, as it were, connected by some relationship to one another" ${ }^{38}$ (Cic., Arch. 2). As a way of showing it practically, Cicero does not let himself be stopped by technicities in his defense to the poet, choosing to adopt an epideictic discourse, not usually used in the forensic context, in which the eulogy of the poet and poetry substitute the traditional proof in judicial disputes. Dugan argues that, when using eulogy in the Pro Archia, Cicero is making use of a mechanism of self-representation typical of the Roman elite, evoking the oration of the laudatio funebris (DUGAN, 2005, p. 37). Besides, the defense that Archias was a legitimate Roman citizen and that his practice had been extremely appreciated by the noble Roman citizens (Cic. Arch, 5), in some way sounded like the attacks Cicero suffered, making his intercession in favor of Archias also an intercession in favor of himself (DUGAN, 2005, p. 45). ${ }^{39}$ In the excerpt in which Cicero admits dedicating to the studies of

\footnotetext{
37 "Cicero's success was founded not on military office, nor specifically on patronage from a powerful nobilis family, but to a greater extent on his oratorical skills and the supporters which his advocacy earned him, including the equites" (VAN DER BLOM, 2010, p. 34).

38 "Etenim omnes artes, quae ad humanitatem pertinent, habent quoddam commune vinculum, et quasi cognatione quadam inter se continentur".

${ }^{39}$ Cicero, for example, when engaging in his defense of Murena, looks surprised by the accusations he received about his ancestry: "non arbitrabar, cum ex familia vetere et inlustri consul designatus ab equitis Romani filio consule defenderetur, de generis novitate accusatores esse dicturos. etenim mihi ipsi accidit ut cum duobus patriciis, altero improbissimo atque audacissimo3, altero modestissimo atque optimo viro, peterem; superavi tamen dignitate
} 
poetry, affirming literature is an excellent way of occupying oneself in moments of idleness, he also affirms the utility of poetry to the speaker, thanks to the many examples brought in the texts that serve to provide the young man with good examples, as well as to instill courage in him (Cic., Arch, 12). When blurring the borders between oratory and poetry, Cicero argue that both constitute the Roman cultural framework - hence why the orator emphasizes that the jury has to understand the chosen tone, for they are, just like himself and Archias, also scholarly and learned men (Cic., Arch, 3). As Nesholm points out, this was the way Cicero had to remember that the civic performance of these men was only possible due to the benefits of the literary education they also had received (NESHOLM, 2010, p. 481). Education is, therefore, presented as a defining key to the Roman ideal, serving as one of its strongest distinctive elements. ${ }^{40}$

This blurring of the border between oratory and poetry is something that Horace also proposed in Epistle 1.3 (23-5), where he suggests that Florus could reach glory through legal practice or through poetry writing - Horace places the two arts on the same landing. Florus also being an individual coming from a family with no grand ancestry, the poet is demonstrating the fact that, by being a cultured and intelligent man, he was able to follow either path, through which he would become important to society. Horace is affirming that a talented young man of obscure birth could succeed, just like himself and Cicero. Like Cicero, Horace presents his educational trajectory throughout his work. Horace's great social ascension occurs precisely because he became a poet, which was only possible, of course, due to the time and money invested in his education. In Epistle 2.2 (v. 41-5) the poet describes: "I had the luck to be educated in Rome and there to be taught how / greatly Achilles' anger harmed the Greeks. Kindly Athens added / a little more training, in the sense that I was eager to distinguish / between the straight and the crooked, and to search for truth amid / the groves of Academus" ${ }^{\prime 21}$.

It is important to notice that it is exactly the study of Homer that is recommended to Lollius in the Epistle 1.2; the indication to study philosophy, search for the truth is the advice of many epistles (c.f. Ep. 1.12, 1.16, 1.18). So, as does Cicero as an orator, Horace presents himself as an ideal poet, not by accident, but precisely because of what he did in life; his formation provided

Catilinam, gratia Galbam. quod si id crimen 4 homini novo esse deberet, profecto mihi neque inimici neque invidi defuissent", "I did not think when a consul-elect of an ancient and illustrious family was being defended by the son of a Roman knight himself a consul, that the accusers would say anything about newness of family. In truth it happened to me myself to stand against two patricians, one a most worthless and audacious man, the other a most modest and virtuous one; yet I surpassed Catiline in worth, Galba in popularity. But if that ought to have been imputed as a crime to a new man, forsooth, I should have wanted neither enemies nor detractors" (Cic. Mur. 17).

${ }^{40}$ As Chiappetta (1997, p. 18) points out, "When we master language, if one is a real master, soon, one is a man of power".

41 "Romae nutriri mihi contigit atque doceri/ iratus Grais quantum nocuisset Achilles./ Adiecere bonae paulo plus artis Athenae, / scilicet ut uellem curuo dinoscere rectum/ atque inter siluas Academi quaerere uerum". 
him success, allowing him to be a model. Brink, for example, demonstrates how Horace in the Epistle 2.1, when describing what he considers excellent poetry, is dislocating the attention of the listener to his own poetic production. Thus, the poet is praising himself, associating what he speaks about with what he does (BRINK, 1963, p. 189).

Another way of demonstrating the auctoritas employed by Cicero and Horace is through the letters of friendship and recommendation. The litterae commendaticiae were an epistolary subgenre well known and utilized in the ancient world. Rees calls attention to the letters produced by Cicero between 46-5 BCE, which were gathered in book 13 of $\mathrm{Ad}$ Familiares (REES, 2007, p. 150). The author argues that since in this period the speaker did not exercise any magistracy, these letters "[...] would serve to heighten appreciation of the influence he was still able to wield through social contacts and networks" (p. 151). That is, although Cicero did not exercise any official position, his years of political experience as well as his literary eminence reached up to that moment ensured his auctoritas. In the letter he introduces Marcus Terentius Varro to Brutus (Fam. 13.10.1) ${ }^{42}$ Cicero says he was convinced that the young Roman's virtues were enough for Brutus to take him in as a friend, but Varro convinced Cicero that a letter written by him would make more of a difference: "But since he had convinced himself that a carefully written letter from me would carry the greatest weight with you and pressed me to write - with the utmost particularity, I thought it better to do what my friend imagined to be of so much importance to him" ${ }^{\prime 3}$. Soon after, he says it is his duty to write this letter (Cic. Fam. 13.10.2). Recommending someone was to put him in an honorable position, a way of showing one's word has great value, and the public exercise of such a role would strengthen the image of those who write.

Friendship recommendations appears in many ways in the Epistles. In the Epistle 1.3, v. 30-5, Horace tries to intervene in Florus' and Munacius' friendship, who were in the middle of a fight; in the Epistle 1.12, v. 22-3, he recommends that Ictius gains Grosphus' friendship ("treat as a friend Pompeius Grosphus, and if he asks you for / anything, grant it freely; Grosphus will ask for nothing that is not right and fair" ${ }^{34}$ ). In Epistle 1.9, however, the recommendation is displayed as if it were a legitimate commendatio. We bring attention to the similarities between the aforementioned piece and Cicero's letter mentioned above. Both authors represent themselves as being forced by friends into writing the commendationes, and both mention that the ones being commended believed in their value and influence over their powerful friends: Tiberius, in the case of Horace, and Brutus, in the case of Cicero.

\footnotetext{
${ }^{42}$ CICERO. Letters to Friends. Edited and translated by D. R. Shackleton Bailey. Cambridge, MA: Harvard University, 2001.

43 "Sed cum sibi ita persuasisset ipse meas de se accurate scriptas litteras maximum apud te pondus habituras, a meque contenderet, ut quam diligentissime scriberem, malui facere, quod meus familiaris tanti sua interesse arbitraretur".

44 "utere Pompeio Grospho et, siquid petet, ultro/ defer; nil Grosphus nisi uerum orabit et aequum".
} 
Horace presents himself attending to Septimius' request, ${ }^{45}$ who would be begging the poet to introduce him to Augustus' son-in-law:

Septimius apparently understands better than anyone else what value you attach to me, Claudius. For when he asks, and by entreaty actually compels me to try to commend him and present him to you, as one who is worthy of the character and family of Nero, whose choice falls only on what is honourable, when he judges that I perform the function of a closer friend, he sees what I am capable of and knows it better than I do myself.

It's true, I gave him many reasons why I should be excused from the duty and allowed to go; but I was afraid I might be thought to have portrayed my influence as less than it is, concealing my own capacities and obliging only myself. In this way, in my eagerness not to be accused of a greater fault, I have stooped to the privileges of a confidence bred by the city. But if you approve of this laying aside of modesty at a friend's request, enroll him as one of your group and regard him as a fine, brave fellow. ${ }^{46}$

(Hor. Ep.1.9)

Only three individuals whose families had illustrious ancestors are Horace's recipients, i.e., Maecenas (Ep. 1.1; 1.7 e 1.19), Torquatus (Ep. 1.5) and Tiberius (MAYER, 1994, p. 8). The latter, at the time of publication, counted little more than 20 years, being, therefore, a young man, like most of the recipients of that book; however, he was a reputed man, next to Augustus (the princeps' son-in-law), who had recently conquered a significant victory against the Parthians, finally recovering the insignia Crassus had lost in $53 \mathrm{BCE}$, reason of shame to the Romans (Suet., Tib. 9). ${ }^{47}$ As in Cicero's 13 th book, ${ }^{48}$ the motive of this letter is to show the poet fulfilling the role of an important public figure, whose recommendation has enough value to address someone with Tiberius' lineage. Here the poet is fulfilling a role that before

\footnotetext{
${ }^{45}$ We don't have any information about this character; possibly the same Septimius of Carmen 2.6.

46 "Septimius, Claudi, nimirum intellegit unus, / quanti me facias; nam cum rogat et prece cogit,/scilicet ut tibi se laudare et tradere coner, / dignum mente domoque legentis honesta Neronis, / munere cum fungi propioris censet amici, / quid possim uidet ac nouit me ualdius ipso./ Multa quidem dixi cur excusatus abirem,/ sed timui mea ne finxisse minora putarer, / dissimulator opis propriae, mibi commodus uni./ Sic ego, maioris fugiens opprobria culpae, / frontis ad urbanae descendi praemia. Quodsi/ depositum laudas ob amici iussa pudorem,/scribe tui gregis hunc et fortem crede bonumque."

${ }^{47}$ SUETONIUS. Lives of the Caesars, v. I. Julius. Augustus. Tiberius. Gaius. Caligula. Translated by J. C. Rolfe. Cambridge, MA: Harvard University, 1914.

48 "The collection becomes a showcase to present Cicero as the master-patron, the influential agent whose judgement, esteem, and contacts make him the ideal man to court” (REES, 2007; p. 152).
} 
belonged to Virgil and Varro, when they presented Horace to Maecenas (Sat. 1.6). As the poet himself had already affirmed in Carmen 2.18 (v. 9-11) rich people sought his friendship due to his good faith and talent; his ingenium was one of the sources of his auctoritas. Tiberius seemed to be interested in literature, according to what Horace demonstrated in the Epistles 1.3 and 1.8 after showing how Augustus' son-in-law surrounded himself with literate men, and also Suetonius (Tib. 70.2), when narrating that Tiberius wrote a poem grieving his brother and imitated Greek poets he very much admired.

Horace demonstrates he makes this recommendation with some reluctance, something connected to an advice given by the poet later, in the Epistle 1.18 (v. 76-8), in which he recommends Lollius to be prudent before doing a commendatio, such as Horace stages in the Epistle 1.9: "Time and again give thought to what kind of a person you are recommending, / in case before long another's shortcomings bring shame / on your head"49. Horace, therefore, being reticent in the epistle to Tiberius creates an inner dialogue in his work, making, in a way, this poem, but also the own poet, an example Lollius should follow. According to Cotton, although the first use of the term litterae commendaticiae was in Cicero, it was something quite common in Roman social life, inside the amicitia relationships (COTTON, 1985, p. 330-331). Horace, trying to mimic that practice in his Epistles, brings to poetry an aspect of the everyday experience, which helps to reinforce with the primary reader the epistolary aspect of this collection.

\section{Conclusion}

Cicero and Horace are men who climbed through the social ranks thanks to the privileged relationships, gathered due to their ingenia and industriae, they earned throughout their lives. As Dugan proposes, in his consolidation as a homo novus, Cicero, in fact, represents something innovative in Rome, for he is a politician whose appeal to power was based on his intellectual feats (DUGAN, 2001, p. 20). Horace seems to follow that same path in the construction of his poet-citizen image, presenting himself as triumphant for being successful in literature. They represented, each in their own manner, a new idea of an elite, of men who are exalted for their efforts and alliances, and not for their heredity, in the context of transformations through which the Roman elite was going in the first century CE and that reaches a peak during Augustus' Principatum, when many equestres gain prominence in the public administration. ${ }^{50}$

\footnotetext{
49 "Qualem commendes, etiam atque etiam aspice, ne mox/ incutiant aliena tibi peccata pudorem./ Fallimur et quondam non dignum tradimus" (Hor. Ep. 1.18. 76-8).

${ }^{50}$ See SALLER, 1980. Ronald Syme (2011, p. 355) affirms that the equestrian order will be the base of Augustus' empire, due to the importance conferred by the princeps, throughout the years, to these men.
} 


\section{Primary sources, translations and editions}

CICERO. Brutus. Orator. Translated by Hendrickson; Hubbell. Cambridge, MA: Harvard University, 1971.

CICERO. Letters to Friends. Edited and translated by D. R. Shackleton Bailey. Cambridge, MA: Harvard University, 2001. 3v.

CICERO. Letters to Quintus and Brutus. Letter Fragments. Letter to Octavian. Invectives. Handbook of Electioneering. Edited and translated by D. R. Shackleton Bailey. Cambridge, MA: Harvard University, 2002.

CICERO. On Duties. Translated by Walter Miller. Cambridge, MA: Harvard University, 1913.

CICERO. On the Republic. On the Laws. Translated by Clinton W. Keyes. Cambridge, MA: Harvard University, 1928.

CICERO. The Orations of Marcus Tullius Cicero. Translated by C. D. Yonge. London: H. G. Bohn, 1856. 4v.

HORACE. Epistles, Book I. Translated by Roland Mayer. Cambridge: Cambridge University, 1994.

HORACE. Satires and Epistles. Translated by John Davie. Oxford: Oxford University, 2011.

SALLUST. The War with Catiline. The War with Jugurtha. Edited by John T. Ramsey. Translated by J. C. Rolfe. Cambridge, MA: Harvard University, 2013.

SUETONIUS. Lives of the Caesars, v. I. Julius. Augustus. Tiberius. Gaius. Caligula. Translated by J. C. Rolfe. Cambridge, MA: Harvard University, 1914.

\section{References}

ALBERTE, Antonio. Coincidencias estético-literarias en la obra de Cicerón y Horacio. Emerita 57, p. 37- 88, 1989.

ATKINS, E. M. Cicero. In: ROWE, Christopher; SCHOFIELD, Malcom (Eds.). The Cambridge History of Greek and Roman Political Thought. Cambridge: Cambridge University, 2000. p. 477-516.

BAILEY, Shackleton. Nobiles and novi reconsidered. The American Journal of Philology, v. 107, p. 255-60, 1986.

BOURDIEU, Pierre. The forms of capital. In: RICHARDSON, John G. (Ed.). Handbook of Theory and Research for the Sociology of Education. New York: Greenwood, 1985. p. 241-258. 
BRINK, Charles Oscar. Horace on poetry: prolegomena to the literary epistles. Cambridge: Cambridge, 1963.

BRUNT, Peter Astbury. Nobilitas e Novitas. The Journal of Roman Studies, v. 72, p. 1-17, 1982.

BURCKHARDT, L. A. The political elite of the Roman Republic: comments on recent discussion of the concepts Nobilitas and Homo Novus. Historia, v. 39, p. 77-99, 1990.

CHIAPPETTA, Angélica. Ad animos faciendos - Comoção, fé e ficção nas Partitiones oratoriae e no De officiis de Cícero. Tese (Doutorado em Letras). FFLCH, Universidade de São Paulo, São Paulo, 1997.

COTTON, Hannah M. Mirificum Genus Commendationis: Cicero and the Latin Letter of Recommendation. The American Journal of Philology, v. 106, n. 3, p. 328-334, 1985.

DAREMBERG, Charles; SAGLIO, Edmond. Dictionnaire des antiquities grecques et romains. Paris: Hachette, 1877, p. 347.

DOLGANOV, Anna. Constructing author and authority: generic discourse in Cicero's De Legibus. The Classical Association, v. 55, n. 1, p. 23-38, 2008.

DUGAN, John. How to Make (and Break) a Cicero: epideixis, textuality, and self-fashioning in the Pro Archia and In Pisonem. Classical Antiquity, v. 20, n. 1, p. 35-77, 2001.

DUGAN, John. Making a New Man: Ciceronian Self-Fashioning in the Rhetorical Works. Oxford: Oxford University, 2005.

DUQUESNAY, Ian M. Le M. Horace and Maecenas: the propaganda value of Sermones I. In: FREUDENBURG, Kirk (Ed.). Horace: Satires and Epistles. Oxford: Oxford University, 2009. p. 42-101.

FLOWER, Harriet I. Ancestor masks and aristocratic power in Roman culture. Oxford: Clarendon, 1999.

GELZER, Matthias. Die Nobilität der römischen Republik. Stuttgart: Teubner, 1912.

MARTINS, Paulo. Vertentes do retrato romano no final da República e no início do Principado. Cadernos de Pesquisa do CDHIS, v. 27, p. 13-38, 2014.

MAYER, Roland. Commentary. In: HORACE. Epistles, Book I. Translated by Roland Mayer. Cambridge: Cambridge University, 1994.

MOMMSEN, Theodor. Römisches Staatsrecht. Leipizig: Hirzel, 1887.

NESHOLM, Erika J. Language and Artistry in Cicero's "Pro Archia". The Classical World, v. 103, n. 4, p. 477-490, 2010.

OLIENSIS, Ellen. Horace and the Rhetoric of Authority. Cambridge: Cambridge University, 1998.

REES, Roger. Letters of Recommendation and the Rhetoric of Praise. In: MORELLO, 
Ruth; MORRISON, Andrew. Ancient Letters: classical and late antique epistolography. Oxford: Oxford University, 2007. p. 149-168.

SALLER, Richard P. Promotion and Patronage in Equestrian Careers. The Journal of Roman Studies, v. 70, p. 44-63, 1980.

STEWART, Peter. Statues in Roman society: representation and response. Oxford: Oxford University, 2011.

STROUP, Sarah Culpepper. Catullus, Cicero, and a Society of Patrons: The Generation of the Text. Cambridge: Cambridge University, 2010.

SYME, Ronald. Augustan Aristocracy. Oxford: Oxford University, 1986.

SYME, Ronald. La Revolución Romana. Traducción de Antonio Blanco Freijeiro. Crítica: Barcelona, 2011. [1st edition: 1939].

VAN DER BLOM, Henriette. Cicero's Role Models: The Political Strategy of a Newcomer. Oxford: Oxford University, 2010.

WISEMAN, Timothy Peter. New Men in the Roman Senate - 139 BC-14 AD. Oxford: University, 1971. 